\title{
HISTÓRIAS DO BRASIL
}

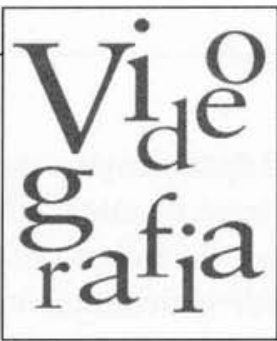

Dando continuidade às sugestões de vídeos que apresentam e favorecem uma reflexão em torno dos 500 anos de nossa trajetória histórica, pensei em trazer para este número 18 da Revista três outros momentos que também merecem um olhar crítico: a mineração e a imigração.

Como a proposta tem sido a de indicar filmes e documentários que tratam de nossa história mas que são pouco conhecidos, selecionei vários títulos para cada um dos temas.

Para discutir o ciclo da mineração, século XVIII, sugiro os documentários: A gaiola de ouro, de Sílvio Back; Morro de Minas, de Bernardo Brant e o filme Xica da Silva, de Carlos Diegues.

\section{A gaiola de ouro \\ Direção: Sílvio Back \\ Produção: Blim Film}

Ano: 1973

Duração: $20 \mathrm{~min}$

Brasil

CDI, MIS ${ }^{2}$

O documentário de Sílvio Back é uma viagem às profundezas da mina de ouro de Morro Velho, em Nova Lima, Minas Gerais. Sua história trata da ilusória mística do ouro e do drama cotidiano dos mineiros.

\section{Morro das Minas}

Direção: Bernardo Brant

Produção: Juscelino de Oliveira

Ano: 1991

Duração:12min

Brasil

A B V P 3

\section{A AUTORA}

Maria Ignês Carlos Magno ${ }^{1}$

Professora de História no ensino fundamental e médio em São Paulo. Doutora em Ciências da Comunicação pela ECAUSP.E-mail: unsignes@usp.br

1. A indicação destes vídeos foi retirada da videografia orientada pelo Prof. Ismar de Oliveira Soares e realizada pelos pesquisadores Antônio Reis Júnior e Patrícia Horta Alves. ECA-USP, 1994.

2. Museu da Imagem e do Som, situado na Av. Europa,158 - Jardim Europa. São Paulo, SP - CEP 01449-000. 
O documentário de Bernando Brant narra as condições de trabalho nas áreas de mineração em Minas Gerais. Faz um resgate da história desta atividade no Estado e mostra a situação atual. Ele aborda a questão do meio ambiente, colocando o ser humano como o elemento que sofre a maior degradação.

\section{Xica da Silva}

Direção: Carlos Diegues

Produção: Globo Vídeo

Duração: $117 \mathrm{~min}$

Ano: 1976

Brasil

$\mathrm{F} \mathrm{D} \mathrm{E}^{4}, \mathrm{~L} \mathrm{C}^{5}$

O filme de Carlos Diegues conta a história de João F. de Oliveira, português, que ao chegar ao Arraial do Tijuco se interessa pela escrava Xica da Silva e a toma como sua mulher.

Todos os três filmes têm como tema básico para discussão o ciclo da mineração do século XVIII até os dias atuais. Especificamente Xica da Silva pode ser abordado tanto pela opulência de Minas Gerais quanto pela escravidão negra no Brasil.

Interessante também é a análise que se pode fazer das três leituras dos cineastas sobre o tema em três momentos diferentes da produção cinematográfica 1973, 1976 e 1991.

Para o tema imigração, os filmes Aleluia Gretchen, Vida e sangue de polaco, ambos de Sílvio Back e Os Mucker, de Jorge Bodanzky e Wolf Ganer proporcionam o conhecimento de outros imigrantes, além dos portugueses, espanhóis e italianos que, por motivos tão singulares quanto os destes, vieram para o Brasil. Trata-se das imigrações alemã e polonesa que se instalaram no Sul do país.

\section{Aleluia Gretchen}

Direção: Sílvio Back

Produção: Sílvio Back Produções Cinematrográficas e Embrafilme.

Ano: 1976

Duração: $118 \mathrm{~min}$

Brasil 


\section{Sangue e Vida de Polaco}

Direção: Sílvio Back

Produção: Secretaria da Cultura e do Esporte do Paraná e Sílvio Back

Ano: 1982

Duração: $56 \mathrm{~min}$

Brasil

\section{Os Muckes}

Direção: Jorge Bodanzky e Wolf Ganer

Produção: Stopfilme

Ano: 1978

Duração: $115 \mathrm{~min}$

Brasil

Aleluia Gretchen é um drama sobre família imigrante alemã, os Kranz, que se instala no Paraná, na década de 1930. O filme mostra as relações e conflitos com o nazismo e o integralismo brasileiro. Também sobre a vida dos imigrantes alemães no Brasil, Os Muckes narra o drama dos descendentes de imigrantes alemães que organizaram uma comunidade auto-suficiente, no século passado, no Rio Grande do Sul. Sangue e vida de Polaco é um documentário sobre a memória social, afetiva, religiosa, política e cultural dos polacos, desde quando chegaram ao País, em 1869, aos dias atuais.

A sugestão desses filmes sobre os povos que para aqui vieram foi pensada sob alguns aspectos: possibilita o estudo dos processos imigratórios para o Brasil; da história de cada um dos povos, em especial a história do povo polonês, tão rica, tão triste e tão pouco abordada nos livros didáticos. Esta proposta pode levar também à pesquisa e à discussão sobre as revoltas populares e a repressão do Estado; e sobre o nazismo e o integralismo: sua ideologia, proximidade e diferença. Essencialmente, esses vídeos abrem um debate sobre os muitos conflitos na nossa trajetória como povo. Um terceiro aspecto encontra-se no fato de podermos, além de pesquisar todos os povos que para cá vieram, pensar a nossa singularidade cultural, a miscigenação, o multiculturalismo, os sincretismos presentes na formação do povo brasileiro. 